\title{
Development and Validation of an HPLC Method Using an Experimental Design for Analysis of Amlodipine Besylate and Enalapril Maleate in a Fixed-dose Combination
}

\author{
Amlodipin Besilat ve Enalapril Maleatın Sabit Dozlu Kombinasyondan \\ Analizi için Deney Tasarımı Yoluyla Bir YBSK Yöntemi Geliştirilmesi ve \\ Validasyonu
}

\author{
(D) Diren SARISALTIK YAŞIN', (D) Alev ARSLANTÜRK BINGÜL², (D) Alptuğ KARAKÜÇÜK33,4, (D) Zeynep Şafak TEKSIN³* \\ 1Dicle University Faculty of Pharmacy, Department of Pharmaceutical Technology, Diyarbakır, Turkey \\ 2Dicle University Faculty of Science, Department of Chemistry, Diyarbakır, Turkey \\ ${ }^{3}$ Gazi University Faculty of Pharmacy, Department of Pharmaceutical Technology, Ankara, Turkey \\ ${ }^{4}$ Ankara Medipol University Faculty of Pharmacy, Department of Pharmaceutical Technology, Ankara, Turkey
}

\begin{abstract}
Objectives: The aim of this study was to develop and optimize a simple, cost-effective, and robust high-performance liquid chromatography (HPLC) method by taking an experimental design approach to the assay and dissolution analysis of amlodipine besylate and enalapril maleate from a fixeddose combination tablet.

Materials and Methods: The chromatographic analysis was performed on a C18 column ( $4.6 \times 250 \mathrm{~mm}$ id., particle size of 5 um). The injection volume was $5 \mu \mathrm{L}$, and the detection wavelength was $215 \mathrm{~nm}$. A Box-Behnken design was used to test the robustness of the method. The flow rate (1, 1.2, and $1.4 \mathrm{~mL} / \mathrm{min}$ ), column temperature $\left(25^{\circ} \mathrm{C}, 30^{\circ} \mathrm{C}\right.$, and $35^{\circ} \mathrm{C}$ ), methanol ratio of the mobile phase $(5,10$, and $15 \%)$, and $\mathrm{pH}$ of the mobile phase $(2.8$, 3 , and 3.2) were selected as independent variables. The method was validated according to International Conference on Harmonization guidelines. Dissolution of the tablets was performed by using USP apparatus 2 and analyzed using the optimized HPLC method. Multivariate linear regression analysis and ANOVA were used in the statistical evaluation.

Results: Linear models were fitted for all variables. The flow rate was the most significant factor affecting the APIs' concentrations. The optimized method included the following parameters: Column temperature of $25^{\circ} \mathrm{C}, 10 \%$ methanol as the mobile phase, $\mathrm{pH}$ of 2.95 , and flow rate of $1.205 \mathrm{~mL} /$ min. Retention times were $3.8 \mathrm{~min}$ and $7.9 \mathrm{~min}$ for enalapril and amlodipine, respectively. The method was found to be linear in the range of $0.8-24$ $\mu \mathrm{g} / \mathrm{mL}\left(R^{2}>0.999\right)$ and $1.6-48 \mu \mathrm{g} / \mathrm{mL}\left(R^{2}>0.999\right)$ for amlodipine and enalapril, respectively. Both APIs were dissolved more than $85 \%$ within 10 min. Conclusion: The experimental design was proved as a useful tool for the determination and separation of enalapril maleate and amlodipine besylate in dosage forms. The optimized method can be used for in vitro performance and quality control tests of fixed-dose tablet combinations containing enalapril maleate and amlodipine besylate.
\end{abstract}

Key words: Amlodipine, enalapril, design of experiment, HPLC, fixed-dose combination

Amaç: Bu çalıșmanın amacı, amlodipin besilat ve enalapril maleat içeren sabit dozlu kombinasyon tabletinden disolüsyon ve miktar tayini analizi için deney tasarımı yaklaşımı ile basit, ekonomik ve sağlam bir yüksek basınçlı sıvı kromatografisi (YBSK) yönteminin geliştirilmesi ve optimizasyonudur. Gereç ve Yöntemler: Kromatografik analiz C18 kolonda $(4,6 \times 250$ mm id., $5 \mu \mathrm{m}$ partikül çapı) gerçekleștirilmiştir. Enjeksiyon hacmi $5 \mu \mathrm{L}$ ve dalga boyu 215 nm'dir. Yöntemin sağlamlığının test edilmesinde Box-Behnken tasarımı kullanılmıștır. Akış hızı (1, 1,2, ve 1,4 mL/dk), kolon sıcaklığı (25C,

*Correspondence: zsteksin@gazi.edu.tr, Phone: +90 31220230 42, ORCID-ID: orcid.org/0000-0001-6359-5935

Received: 05.05.2020, Accepted: 29.06.2020

The manuscript was presented at the International Symposium on Pharmaceutical Sciences (ISOPS-12) on June 28, 2018 in Ankara, Turkey.

๑Turk J Pharm Sci, Published by Galenos Publishing House. 
$30^{\circ} \mathrm{C}$ ve $35^{\circ} \mathrm{C}$ ), hareketli fazdaki metanol oranı (\%5, \%10 ve \%15) ve hareketli fazın pH'sı $(2,8,3$ ve 3,2) bağımsız değișkenler olarak seçilmiştir. Yöntemin validasyonu ICH kılavuzlarına göre gerçekleștirilmiștir. Tabletlerin çözünme hızı deneyleri USP cihaz 2 kullanılarak 75 devir/dk hızda gerçekleștirilmiştir. Çözünme hızı çalışması $0,1 \mathrm{~N} \mathrm{HCl}$ da $37 \pm 0,5^{\circ} \mathrm{C}^{\prime}$ de yapılmış ve optimize edilen YBSK yöntemi ile analiz edilmiştir. İstatistiksel değerlendirmede çok değişkenli doğrusal regresyon analizi ve ANOVA testi kullanılmıştır.

Bulgular: Tüm değişkenler için doğrusal modeller kullanılmıştır. Etkin madde konsantrasyonlarını etkileyen en anlamlı faktör akış hızıdır. Optimize edilen yöntem șu parametreleri içermektedir: $25^{\circ} \mathrm{C}$ kolon sıcaklığı, hareketli fazda \%10 metanol oranı, 2,95 hareketli faz pH'sı ve 1,205 mL/dk akış hızı. Alıkonma zamanları enalapril ve amlodipine için sırasıyla 3,8 dk ve 7,9 dk olarak bulunmuştur. Yöntem amlodipin ve enalapril için sırasıyla 0,8-24 $\mu \mathrm{g} / \mathrm{mL}\left(R^{2}>0,999\right)$ ve 1,6-48 ( $\left.R^{2}>0,999\right) \mu \mathrm{g} / \mathrm{mL}$ aralıkta doğrusal bulunmuştur. Her iki etkin madde de 10 dakika içinde \%85'ten fazla çözünmüștür.

Sonuç: Enalapril maleat ve amlodipin besilatın dozaj formlarından analizinde deney tasarımı faydalı bir yaklașım olarak görülmüştür. Optimize edilen yöntemin enalapril ve amlodipin içeren bir sabit dozlu kombinasyonun in vitro performansı ve kalite kontrol testlerinde kullanılabileceği gösterilmiştir.

Anahtar kelimeler: Amlodipin, enalapril, deney tasarımı, YBSK, sabit dozlu kombinasyon

\section{INTRODUCTION}

At the early stages of the treatment of hypertension, it can be useful to choose monotherapy to observe the effect and the side effects of the drug. However, monotherapy can be insufficient to reach the target blood pressure in a majority of patients. ${ }^{1-3}$ A greater therapeutic benefit can be achieved with two or even more antihypertensive drugs. ${ }^{4}$ Therefore, fixed-dose combinations (FDCs) are frequently used in cardiovascular diseases such as hypertension. In order to develop an FDC product including two drugs, certain conditions must be met. For instance, a synergistic effect can be observed using two drugs together, or a side effect related to a drug may be eliminated using the other drug concurrently. ${ }^{5}$ In the treatment of hypertension, there is a synergistic effect between calcium channel blockers (CCBs) and angiotensin-converting enzyme inhibitors (ACEIs). In addition, ACEls such as enalapril prevent peripheral edema caused by CCBs such as amlodipine. ${ }^{6}$

Amlodipine is a long-acting CCB that inhibits the transmembrane influx of calcium ions into vascular smooth muscle and cardiac muscle. It is indicated for the treatment of hypertension and coronary artery disease when used alone or in combination with another antihypertensive agent. ${ }^{7}$ Amlodipine is given orally as besylate in general, but doses are calculated in terms of amlodipine base. A dose of $6.94 \mathrm{mg}$ of amlodipine besylate is equivalent to $5 \mathrm{mg}$ of amlodipine base. The recommended dose of amlodipine is 5-10 mg once daily. ${ }^{8}$ Since amlodipine is a weak base, it exhibits high solubility in physiological $\mathrm{pH}$ values. Although the bioavailability of amlodipine is approximately $60 \%-65 \%$, it is defined as a highly permeable drug because of the $90 \%-95 \%$ excretion rate as an inactive metabolite in the urine Shohin et al. ${ }^{9}$ Amlodipine is a class 1 drug according to the Biopharmaceutics Classification System (BCS). ${ }^{9-11}$

Enalapril is the ethyl ester of enalaprilat, an ACEI indicated for the treatment of hypertension and heart failure. Enalapril is available as maleate salt in the drug market. Enalapril maleate is a white crystalline powder sparingly soluble in water. Although the solubility is $25 \mathrm{mg} / \mathrm{mL}$ at $\mathrm{pH} 3.5$, it increases to $200 \mathrm{mg} / \mathrm{mL}$ at $\mathrm{pH}$ 7.0. It is defined as BCS class 3 with high solubility but low permeability properties. ${ }^{12}$

There are high-performance liquid chromatography (HPLC) methods recommended in United States Pharmacopeia (USP42) for analysis of amlodipine besylate ${ }^{13}$ and enalapril maleate, ${ }^{14}$ separately and a few liquid chromatography methods are available in the literature for analyses of amlodipine, ${ }^{15}$ and enalapril, ${ }^{16,17}$ individually or in combination with other drugs. ${ }^{18-23}$ However, these methods are not suitable for the separation of amlodipine and enalapril in the same dosage unit. Nevertheless, there are three published articles for HPLC analysis of amlodipine besylate and enalapril maleate together in dosage forms. ${ }^{24-26}$ However these methods contain a high ratio of organic solvents in the mobile phase, which is environmentally inappropriate according to the green chemistry approach. An important principle of green chemistry is to reduce toxic organic solvents and to consume safer chemicals. ${ }^{27,28}$ Relating to the green analytical chemistry approach, Korany et $a .^{27}$ recommended reducing the acetonitrile amount in the methods and using multiparameter methods such as design of experiment (DOE) instead of the one factor at a time (OFAT) approach. ${ }^{28}$ In the method developed by Chaudhari ${ }^{24}$, the mobile phase contains $50 \%$ acetonitrile and $40 \%$ methanol and a higher injection volume $(20 \mu \mathrm{L})$, which increases the consumption of mobile phase and the linearity range was comparatively narrow (0.5-6 $\mu \mathrm{g} / \mathrm{mL}$ and $0.5-8 \mu \mathrm{g} / \mathrm{mL}$ for enalapril and amlodipine, respectively). In another method, the mobile phase includes $60 \%$ acetonitrile, the injection volume was $20 \mu \mathrm{L}$, and the linearity range was not suitable for lower concentrations (20$100 \mu \mathrm{g} / \mathrm{mL}$ ), which might be essential for the initial points of the dissolution tests. ${ }^{25}$ In the method developed by Masih et al. ${ }^{26}$, $50 \% 1 \mathrm{~N} \mathrm{HCl}$ and $50 \%$ methanol were included in the mobile phase, and the injection volume was $10 \mu \mathrm{L}$. Additionally, none of the studies include the application of DOE in robustness testing in validation for amlodipine besylate and enalapril maleate. Furthermore, there is no dissolution analysis of enalapril and amlodipine in the combined dosage form in the literature.

DOE is a well-defined mathematical methodology to demonstrate how to obtain maximum reliable and valuable scientific information by performing minimal experiments. ${ }^{29}$ In this technique, the effects of multiple variations on one or more responses can be investigated at the same time, instead of changing OFAT. Although conventional developmental approaches are mainly empirical and are often conducted using the changing OFAT method, DOE provides the facility of performing systematic and multivariate experiments in order to entirely understand the process and to assess the statistical significance of the variables. ${ }^{30,31}$ By creating experimental 
matrix, DOE allows faster visualization and determination of more factors at a time. ${ }^{32}$ Besides, in OFAT approach factors are evaluated independently, so it is assumed that the factors do not influence each other. However, the potential interactions between the factors can be identified using the appropriate DOE model. ${ }^{33,34}$ In the pharmaceutical field, DOE helps to understand the effects of the critical formulation and process variables on the final product. 35,36 DOE can be used for factor screening and characterization of a new system or optimization of a characterized system. Factors are independent variables that might affect the results of critical responses. For instance, in an analytical method development process, the flow rate can be an independent factor that has potential effects on the peak area of the analyte. In a screening design it is aimed to investigate numerous factors that might affect the response and to discover the factor which has the most significant influence on the responses. ${ }^{37}$ On the other hand, in an optimization process, the main objective of which is to define the optimal conditions and settings for the factors. ${ }^{38}$ In case more than one factor must be examined, the multivariate optimization designs can be reasonable in order to evaluate different factors at the same time and to determine if interactions exist between factors. ${ }^{37,38}$

In analytical chemistry, DOE can be used for chromatographic analytical method development to optimize the sampling preparational, column, detector, instrumental, or environmental factors. ${ }^{31,39}$ Similarly, analytical method validation parameters such as accuracy, linearity, precision, or robustness can be

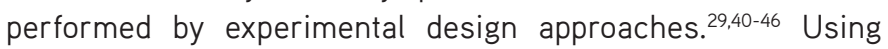
DOE in validation studies is recommended in the International Conference on Harmonization (ICH) guidelines. ${ }^{27,47}$ There have been many studies in which DOE was applied to robustness. . $^{31,32,43,48,49}$ Experimental design targeting robustness is a good approach to fully understand the factors with effects on the responses and provide maximum information about the method in a short time. Robustness should be built into methods in the pre-validation stages; otherwise, a robustness test performed too late has a risk of obtaining inappropriate results which can cause redevelopment and revalidation. ${ }^{50}$ Therefore, a robustness test in the earlier stage of the method development process leads to a saving of effort, time, and money. Experimental data obtained from early stages can aid in performance method evaluation and can be used to guide further method development. ${ }^{51}$

Optimization can be performed by using response surface methodology (RSM) designs such as the Box-Behnken design (BBD) and the central composite design (CCD). ${ }^{49,52}$ The BBD is a second-order design that allows investigation of numerous factors with three levels. It is preferable to the CCD because it prevents an unrealistic extreme scenario by creating the experimental matrix without containing extreme points in the same experiment. ${ }^{33,52}$ BBD is used in analytical method optimization in many studies. ${ }^{6} 48,53-65$

In this study, a simple, rapid and robust HPLC method with photodiode array (PDA) detection at $215 \mathrm{~nm}$ was developed for the determination and separation of amlodipine besylate and enalapril maleate in FDC tablets. This method, which is available for assay and dissolution studies, was fast, environmentally friendly, and more cost-effective than the earlier published methods. ${ }^{24-26}$ In this study, DOE was adapted to the robustness parameter of the analytical method for determining amlodipine and enalapril together. DOE principles were used in the method development of amlodipine and enalapril for the first time. The validation of the method was performed according to the $\mathrm{ICH}$ Q2 (R1) guideline.47 The BBD was used for the optimization of the method. The optimized HPLC method was applied to dissolution and assay analysis of an in-house FDC tablet including amlodipine and enalapril.

\section{MATERIALS AND METHODS}

\section{Materials and reagents}

HPLC-grade methanol, o-phosphoric acid and hydrochloric acid $37 \%$ were obtained from Merck, Germany. Amlodipine besylate (Hetero Drugs, India) and enalapril maleate (Zheijiang Huahai, China) were kindly gifted by Nobel Pharma, Turkey.

The FDC tablet contains $6.94 \mathrm{mg}$ of amlodipine besylate and 10 $\mathrm{mg}$ of enalapril maleate as APIs.

\section{Apparatus}

The HPLC system was a Shimadzu chromatographic system (Japan) with LC-20AD pump, SPD-M20A PDA detector at a wavelength of $215 \mathrm{~nm}$, a reversed phase $\mathrm{C} 18$ column $(4.6 \times 250$ $\mathrm{mm}$ id., particle size of $5 \mu \mathrm{m}$ ) from Waters ${ }^{\circledR}$ (USA). The HPLC system was controlled by LC Solution Software. Design Expert ${ }^{\circledR}$ Version 9 (Stat-Ease Inc, USA) was used for the experimental design and statistical analysis of data. A pH meter (PASS1 P11BNC-Bante, England) was used to control the aqueous buffer. Dissolution test was performed with Pharmatest ${ }^{\circledR}$ Dissolution System (Germany).

\section{Chromatographic conditions}

The mobile phase was a mixture of methanol and water $(\mathrm{pH}$ adjusted to 3.0 with o-phosphoric acid) in the proportion of 10:90 (v:v). The injection volume of the samples was $5 \mu \mathrm{L}$. The flow rate was $1.2 \mathrm{~mL} / \mathrm{min}$. The detector wavelength was $215 \mathrm{~nm}$ and the column temperature was $30^{\circ} \mathrm{C}$.

\section{Preparation of standard solutions}

The standard solution was prepared according to the following process: $6.94 \mathrm{mg}$ of amlodipine besylate (equivalent to $5 \mathrm{mg}$ amlodipine base) and $10 \mathrm{mg}$ of enalapril maleate were weighed and transferred to a $50 \mathrm{~mL}$ volumetric flask and diluted to the appropriate volume with $0.1 \mathrm{~N} \mathrm{HCl}$. This solution included $0.1 \mathrm{mg} /$ $\mathrm{mL}$ of amlodipine base and $0.2 \mathrm{mg} / \mathrm{mL}$ of enalapril maleate. The calculations were performed considering amlodipine base and enalapril as maleate salts because of the dose proportionality in market products.

\section{Calibration procedure}

Calibration series were prepared in volumetric flasks by the appropriate dilution of standard solution with $0.1 \mathrm{~N} \mathrm{HCl}$. The calibration curve was plotted with eight concentrations in the 
range of $0.8-24 \mu \mathrm{g} / \mathrm{mL}$ for amlodipine and $1.6-48 \mu \mathrm{g} / \mathrm{mL}$ for enalapril (as maleate). The experiments were performed in three replicates for each level. The linearity of the calibration curve was evaluated by the linear regression statistics of concentrations against peak area.

\section{Statistical analysis}

\section{Experimental design}

Experimental plan, data analysis and optimization process were executed in Design Expert ${ }^{\circledR}$ Version 9 by using the BBD. The BBD is a three-level and multi-factor design which is a combination of $2 \mathrm{~K}$ factorial and balanced incomplete block designs. In this study, four factors with three levels for each were determined as given in Table 1.

The significant factors in the model were determined by multivariate linear regression analysis and ANOVA F-test and its lack of fit with a confidence interval of $95 \%$ for each response. Significant factors were determined by the probability level that the $p$ value is less than 0.05 and one-factor graphs.

\section{Assay in FDC tablets}

The FDC tablet containing amlodipine besylate and enalapril maleate was prepared by using direct compression method. For assay of the tablets, 10 tablets for each product were selected at random and weighed. Then these tablets were powdered, and a quantity of the powder (equivalent to $5 \mathrm{mg}$ of amlodipine and $10 \mathrm{mg}$ of enalapril maleate) was accurately weighed and transferred to a $50 \mathrm{~mL}$ volumetric flask. A $30 \mathrm{~mL}$ volume of diluent solution $(0.1 \mathrm{~N} \mathrm{HCl})$ was added and mixed for $15 \mathrm{~min}$ in magnetic stirrer. Then, it was diluted with the same solution to the volume and mixed in an ultrasonic bath for $10 \mathrm{~min}$. A $4 \mathrm{~mL}$ volume of this solution was transferred to a $25 \mathrm{~mL}$ volumetric flask and diluted to the volume using the same solvent and was held in an ultrasonic bath for $5 \mathrm{~min}$. The samples were filtered through a syringe tip filter of $0.45-\mu m$ pore size and then analyzed using HPLC.

\section{Dissolution studies}

Dissolution studies were performed using USP apparatus II (paddle method) in $0.1 \mathrm{~N} \mathrm{HCl}(\mathrm{pH} \mathrm{1.2)}$. The dissolution volume was $900 \mathrm{~mL}$, and the temperature was $37^{\circ} \mathrm{C} \pm 0.5^{\circ} \mathrm{C}$. The paddle rotational speed was $75 \mathrm{rpm}$. Samples $(2 \mathrm{~mL}$ ) were withdrawn at $10,20,30,45$, and $60 \mathrm{~min}$, and the same amount of fresh media was replaced. The samples were filtered through $0.45-$ $\mu \mathrm{m}$ membrane filters to vials and analyzed by the optimized HPLC method. The dissolution profiles were evaluated as the cumulative drug dissolved (\%) over time. All experiments were

Table 1. Experimental design

\begin{tabular}{llll} 
Factors & Low level & Nominal level & High level \\
\hline $\begin{array}{l}\text { Methanol ratio in the } \\
\text { mobile phase }(\%)\end{array}$ & 5 & 10 & 15 \\
\hline Flow rate $(\mathrm{mL} / \mathrm{min})$ & 1.0 & 1.2 & 1.4 \\
\hline $\mathrm{pH}$ of the mobile phase & 2.8 & 3.0 & 3.2 \\
\hline Column temperature $\left({ }^{\circ} \mathrm{C}\right)$ & 25 & 30 & 35 \\
\hline
\end{tabular}

performed in $\mathrm{n}=3$ and the cumulative amounts were evaluated as the mean \pm standard deviation (SD).

\section{RESULTS AND DISCUSSION}

The chromatograms of diluent (blank) and those obtained from the standard solutions of amlodipine and enalapril are given in Figure 1, 2 respectively. The initial method provided good separation in a short time of $3.8 \mathrm{~min}$ for enalapril and 7.9 min for amlodipine. This level of separation is acceptable in a conventional method development process. A robustness study with DOE was also performed.

\section{Robustness with DOE principles}

According to the ICH Q2 (R1), in a robust method, small variations in certain method parameters do not affect the reliability and results of the method. ${ }^{47}$ These small variations are important for the pharmaceutical industry in terms of the transfer of the analytical method from research and development to the quality control laboratory or from one company to another. In other words, it is the indication of the strength of the method. ${ }^{51}$ In order to assess the concurrent influences of the changes in factors on the defined responses, a multivariate analysis by DOE is recommended in robustness studies. ${ }^{43}$ DOE is used in analytical method development for two main purposes: To determine the most significant factor influencing the response of the study and to discover the optimized value of the factors for best results for the response. ${ }^{37}$

The DOE plan in a robustness test includes the following stages: $:^{31}$

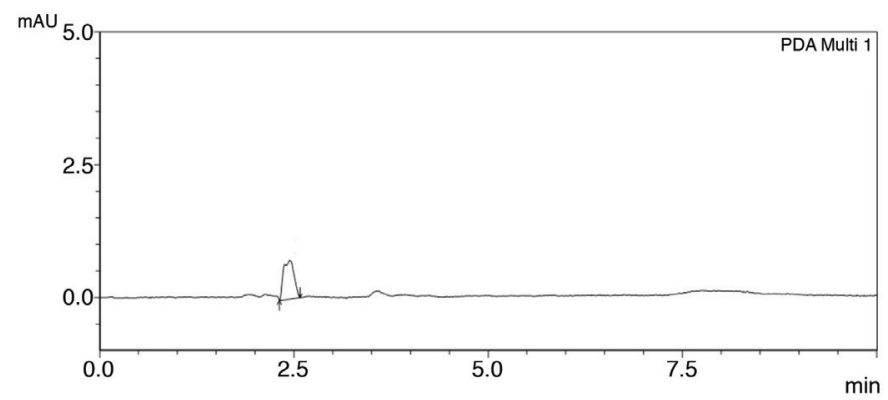

Figure 1. Chromatogram of the placebo (blank medium) for specificity testing

PDA: Photodiode array

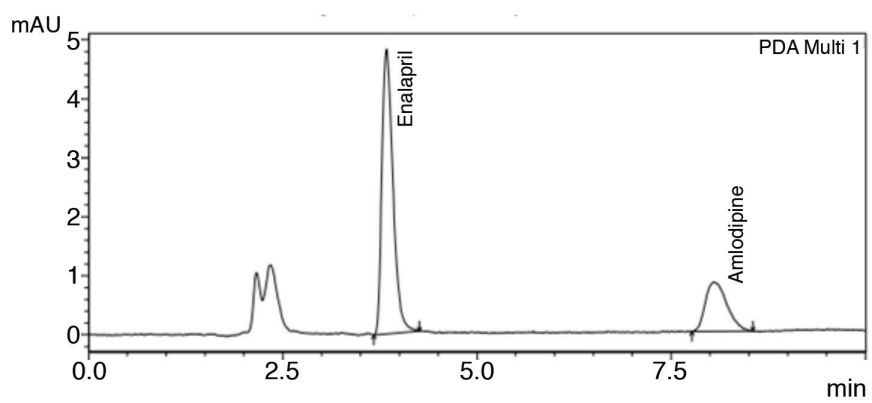

Figure 2. Chromatogram of enalapril ( $8 \mu \mathrm{g} / \mathrm{mL}$, as maleate) and amlodipine $(4 \mu \mathrm{g} / \mathrm{mL})$ in the initial method

PDA: Photodiode array 


\section{Selection of factors and their levels}

Robustness studies are an excellent opportunity to apply statistical experimental design to provide data-based control of the method. ${ }^{51}$ Since there are many factors that might affect the method, it is vital to choose the right factors. In robustness studies of liquid chromatography, the most frequently preferred factors are the $\mathrm{pH}$ of the mobile phase, analysis time, flow rate, column type, temperature, composition of the mobile phase, detection wavelength, chosen filters, or the variations in sample preparation such as dilution, shaking time, or heating temperature. ${ }^{39,51}$ It should be noted that there are no absolute truths in selecting factors in a DOE process; the chosen factors should comply with the purpose. According to ICH Q2 (R1), the following variations were recommended for the robustness test of HPLC methods: 1) $\mathrm{pH}$ of the mobile phase, 2) composition of the mobile phase, 3) column type, 4) temperature, and 5) flow rate. Except for the column type, all recommended factors (mobile phase ratio, $\mathrm{pH}$, flow rate, and column temperature) were investigated in this study. The chosen factors and their pre-defined levels have the potential to affect the method depending on the analyst, laboratory or equipment, and environmental conditions. ${ }^{47}$

After selecting the factors, it is necessary to define their levels. In a two-level model such as Plackett-Burman Design (PBD) or two-level factorial designs, a maximum and a minimum limit are required for the factor values. In three-level designs, additional middle values, which generally represent the target or the expected value, are added to the design. Defining the levels is a critical step in experimental design. Particularly in two-level designs in which inappropriate levels were used, inaccurate and low-quality results can be obtained. ${ }^{33}$ In order to avoid this problem, a three-level BBD design is preferred. The levels of the factors are usually defined symmetrically around the nominal level, which is the middle level in a three-level design. The interval chosen between the levels is generally decided according to the operator's personal experiences or anticipated changes from one laboratory to another. For example, if the developed method will be transferred to another laboratory, the $\mathrm{pH}$ can be measured using a $\mathrm{pH}$ meter with a small deviation, so $\mathrm{pH}$ should be considered as critical. The $\mathrm{pH}$ of a solution varies with a deviation of 0.02 with a confidence limit of $95 \% .{ }^{50}$ Therefore, this limit is acceptable for the $\mathrm{pH}$ in a robustness test. The interval of $\mathrm{pH}$ was \pm 0.02 in this study. The levels of column temperature were decided $\pm 5^{\circ} \mathrm{C}$ as recommended in the article by Vander-Heyden et al. ${ }^{50}$, which was aimed to guide a robustness parameter in method development. The levels of other factors, selected as $5 \%$ for mobile phase composition and $0.2 \mathrm{~mL} / \mathrm{min}$ for flow rate, were in agreement with previous similar studies. ${ }^{32,43,65}$

\section{Defining responses to be investigated}

In the HPLC studies where robustness was investigated by DOE, various responses such as peak area, peak height, determined concentration, retention time, tailing factor, theoretical plate number, and resolution were used. The most important selection criterion for a response to use in factor evaluation is ease of measurement. ${ }^{39}$ Additionally, using a large number of responses can lead to confusion when interpreting the results. Therefore, API concentrations calculated from the peak areas were selected as responses in this study.

\section{Choosing an experimental design}

A suitable experimental design should be selected based on the aim of the study. In case a large number of factors might affect the method, the aim can be to discard some factors that have no significant effect on the response. For this purpose, a screening design such as PBD can be used. On the other hand, if the main objective is to investigate the effects of the relatively lower number of factors deeply, or optimize the most effective factors, optimization designs should be preferred..$^{31}$ Generally, optimization is carried out following determination of the most significant factors by screening design. In case there is a factor known to be highly effective in the separation (such a flow rate or temperature), optimization designs can be preferred directly. ${ }^{37}$ In this study, factors that may affect the results, such as the column temperature, flow rate, and composition of the mobile phase, were chosen with the purpose of performing an optimization. Another reason for choosing an RSM design is to observe any interaction between the factors.

The most used RSM designs are CCD and BBD. BBD requires the fewest experiments among the RSM designs because it does not contain values that are maximum or minimum values in the experimental matrix. ${ }^{33}$ Since BBD requires fewer experiments, and the experimental matrix does not contain the highest or lowest level in the combination, this experimental design prevents an unrealistic extreme scenario. Therefore, the experiment number, time, and cost are reduced. BBD can evaluate the linear and non-linear effects of factors. ${ }^{34,66}$ Thus, BBD was selected for the experimental plan, data analysis and optimization process using the Design Expert ${ }^{\circledR}$ Version 9 software.

\section{Execution of experiments}

Experimental executions were computed by Design Expert Software. Robustness was assessed by using BBD with 29 runs. Experimental design and calculated concentrations of enalapril (as maleate) and amlodipine and the corresponding responses are given in Table 2.

\section{Statistical evaluation of responses and their interpretations}

The best fit model was linear for all factors and their responses. In the literature, linear analysis is frequently indicated and recommended in robustness tests..$^{29,30}$ Therefore, our results were as expected. Linear models are used to show the main effects of factors.

The equation model for $Y_{1}$ (enalapril concentration) and $Y_{2}$ (amlodipine concentration) was as follows:

$$
Y_{1}=32.32+0.079 X_{1}-5.32 X_{2}+0.11 X_{3}+0.51 X_{4} \quad \text { (Equation 1) }
$$

$Y_{2}=16.19+0.12 X_{1}-2.72 X_{2}+0.020 X_{3}+0.021 X_{4} \quad$ (Equation 2) 
Where, $X_{1}$ is column temperature, $X_{2}$ is flow rate, $X_{3}$ is the methanol ratio in the mobile phase, and $X_{4}$ is the $\mathrm{pH}$ of the mobile phase.

The ANOVA results are given in Table 3. The significant effects showed a p value less than 0.05, a low SD (CV \%), and a high adjusted $R$-square (adj $R^{2}$ ) value indicating a good relationship between the experimental data and those of the fitted model. The predicted $R$-square (pred $R^{2}$ ) value was in agreement with the adj $\mathrm{R}^{2}$ for all responses.

The one-factor graphs (Figure 3,4) demonstrated that the flow rate was the most significant factor on the responses; inverse proportionality was found $(p<0.05)$. It was revealed that the

Table 2. Experimental plan for robustness and calculated responses

\begin{tabular}{|c|c|c|c|c|c|c|}
\hline & Factors & & & & Responses & \\
\hline Run & $\begin{array}{l}\text { Column temperature } \\
\left({ }^{\circ} \mathrm{C}\right)\end{array}$ & $\begin{array}{l}\text { Flow rate } \\
(\mathrm{mL} / \mathrm{min})\end{array}$ & $\begin{array}{l}\text { Methanol ratio } \\
(\%)\end{array}$ & $\begin{array}{l}\text { Mobile phase } \\
\mathrm{pH}\end{array}$ & $\begin{array}{l}\text { Amlodipine concentration } \\
(\mu \mathrm{g} / \mathrm{mL})\end{array}$ & $\begin{array}{l}\text { Enalapril maleate concentration } \\
(\mu \mathrm{g} / \mathrm{mL})\end{array}$ \\
\hline 1 & 30 & 1.2 & 5 & 3.2 & 15.888 & 32.058 \\
\hline 2 & 30 & 1.2 & 10 & 3.0 & 16.171 & 32.090 \\
\hline 3 & 35 & 1.4 & 10 & 3.0 & 13.729 & 27.696 \\
\hline 4 & 25 & 1.0 & 10 & 3.0 & 18.749 & 37.797 \\
\hline 5 & 30 & 1.2 & 10 & 3.0 & 15.991 & 31.951 \\
\hline 6 & 25 & 1.2 & 5 & 3.0 & 15.998 & 31.954 \\
\hline 7 & 30 & 1.4 & 10 & 3.2 & 13.837 & 28.039 \\
\hline 8 & 35 & 1.2 & 15 & 3.0 & 16.102 & 32.001 \\
\hline 9 & 30 & 1.2 & 15 & 2.8 & 15.954 & 31.684 \\
\hline 10 & 25 & 1.2 & 15 & 3.0 & 16.047 & 32.003 \\
\hline 11 & 25 & 1.2 & 10 & 3.2 & 16.051 & 32.185 \\
\hline 12 & 35 & 1.2 & 5 & 3.0 & 16.078 & 31.909 \\
\hline 13 & 25 & 1.4 & 10 & 3.0 & 13.022 & 27.539 \\
\hline 14 & 30 & 1.4 & 5 & 3.0 & 13.822 & 27.465 \\
\hline 15 & 30 & 1.0 & 5 & 3.0 & 19.209 & 38.283 \\
\hline 16 & 30 & 1.2 & 15 & 3.2 & 16.084 & 32.385 \\
\hline 17 & 30 & 1.2 & 10 & 3.0 & 16.059 & 31.844 \\
\hline 18 & 35 & 1.2 & 10 & 2.8 & 16.045 & 31.391 \\
\hline 19 & 35 & 1.2 & 10 & 3.2 & 16.099 & 32.295 \\
\hline 20 & 30 & 1.2 & 10 & 3.0 & 16.083 & 31.960 \\
\hline 21 & 30 & 1.2 & 5 & 2.8 & 16.137 & 31.772 \\
\hline 22 & 35 & 1.0 & 10 & 3.0 & 19.132 & 38.345 \\
\hline 23 & 30 & 1.2 & 10 & 3.0 & 16.094 & 31.998 \\
\hline 24 & 30 & 1.4 & 15 & 3.0 & 13.868 & 27.869 \\
\hline 25 & 25 & 1.2 & 10 & 2.8 & 15.920 & 31.214 \\
\hline 26 & 30 & 1.0 & 15 & 3.0 & 19.321 & 38.836 \\
\hline 27 & 30 & 1.4 & 10 & 2.8 & 13.721 & 26.818 \\
\hline 28 & 30 & 1.0 & 10 & 2.8 & 19.084 & 36.981 \\
\hline 29 & 30 & 1.0 & 10 & 3.2 & 19.149 & 39.053 \\
\hline
\end{tabular}

Table 3. ANOVA results

\begin{tabular}{llllllllll} 
Responses & $\pm \mathrm{SD}$ & Mean & $\mathrm{CV} \%$ & Press & $\mathrm{R}^{2}$ & Adj $^{2}$ & Pred $^{2}$ & Adeq precision & $\mathrm{p}$ value \\
\hline Amlodipine & 0.24 & 16.19 & 1.51 & 2.21 & 0.984 & 0.982 & 0.976 & 55.91 & $<0.0001$ \\
\hline Enalapril maleate & 0.59 & 32.32 & 1.82 & 12.69 & 0.976 & 0.972 & 0.964 & 47.76 & $<0.0001$ \\
\hline
\end{tabular}

SD: Standard deviation, CV: Cardiovascular, Adj R²: Adjusted R-square 
most critical factor in robustness is the flow rate. The methanol ratio in mobile phase, temperature, and $\mathrm{pH}$ had no significant effect on the calculated concentrations of amlodipine and enalapril in defined levels. Kovacs et al. ${ }^{30}$ have evaluated the same factors in their robustness test with different responses such as peak asymmetry and retention time. They found that the proportion of methanol in the mobile phase had a significant effect on the retention time of strontium ranelate. Similarly, Dhumal et al. ${ }^{32}$ found that the proportion of methanol in the mobile phase and the flow rate had a negative effect, while the $\mathrm{pH}$ had a positive effect on the peak area and the determined tapentadol concentration. In another study, in which the same factors and different responses (tailing factor, retention time and theoretical plate) were used, the most effective factors were found to be the methanol composition and $\mathrm{pH}^{4}{ }^{45}$ However, the significance of factors depends on the APIs and chromatographic conditions. If we had defined our levels more broadly for other factors (methanol ratio, temperature, and $\mathrm{pH}$ ) or if we had assessed more responses such as tailing factor or resolution we might have observed a meaningful effect with



A: Column Temperature (Celcius)



C: Methanol ratio (\%) other factors. However, this was not considered to be an error in the design because the DOE is specific to the purpose. In this study, we would like to see how possible rational changes would affect the analytical results, rather than creating a design space based on the extreme values of factors.

Two-way interactions between independent variables were found to be insignificant ( $p>0.05$ ). Therefore, a simple screening design, such as a PBD, which is the most popular design in robustness evaluation, might be used in this study. ${ }^{37}$ However, since PBD is a two-level design, it can cause inaccurate statistical evaluations when unsuitable factor levels are selected or when there might be an interaction between the factors. If an experimental model is needed to determine tolerable variations, an optimization design is recommended by Sahu et al. ${ }^{31}$ For this reason, as discussed before, we preferred a BBD that contained a third level (target middle level) and provided more information about the method. There have been similar studies with other drugs in which calculated drug concentrations were the only response and flow rate was the only significant factor in the response..$^{43,46}$

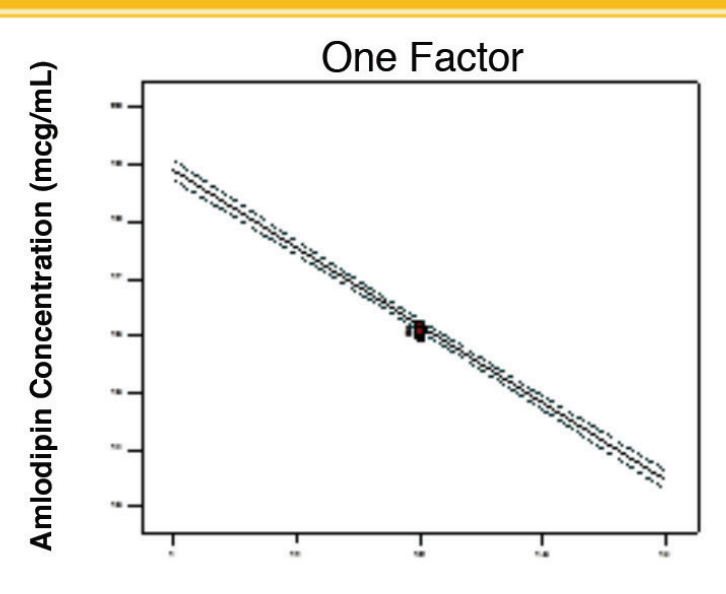

B: Flow Rate (mL/min)

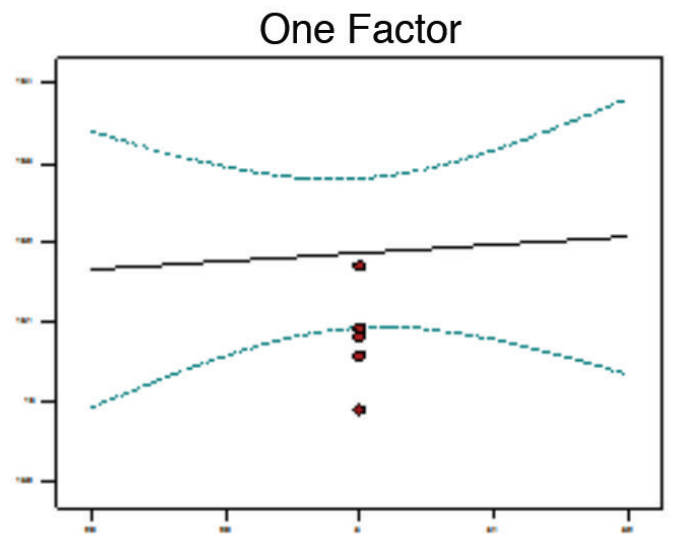

D: Mobile phase $\mathrm{pH}$

Figure 3. A-D) One-factor graphs of the main effects of the factors on amlodipine concentration 


\section{Optimization}

Following linear model fitting, an optimization run was performed, and factor settings were defined using the prediction spreadsheet of the software (Figure 5). The final optimized parameters were a flow rate of $1.205 \mathrm{~mL} / \mathrm{min}, \mathrm{pH}$ of 2.95 , and column temperature of $25^{\circ} \mathrm{C}$. The factors described in the optimization were very close to the nominal levels in the BBD design. Non-etheless, these minor changes caused a better peak shape for amlodipine and a lower tailing factor (from 1.417 to $1.164, p<0.05$ ) (Figure 6). Retention times were not changed in the method with $3.8 \mathrm{~min}$ and $7.9 \mathrm{~min}$ for enalapril and amlodipine, respectively.

The optimized method was validated based on international guidelines.

\section{Linearity}

The linearity of the peak area versus concentration was shown in the range of $0.8-24 \mu \mathrm{g} / \mathrm{mL}$ for amlodipine and 1.6$48 \mu \mathrm{g} / \mathrm{mL}$ for enalapril (as maleate). Linearity results were given in Table 4. The linearity range was kept wider than the

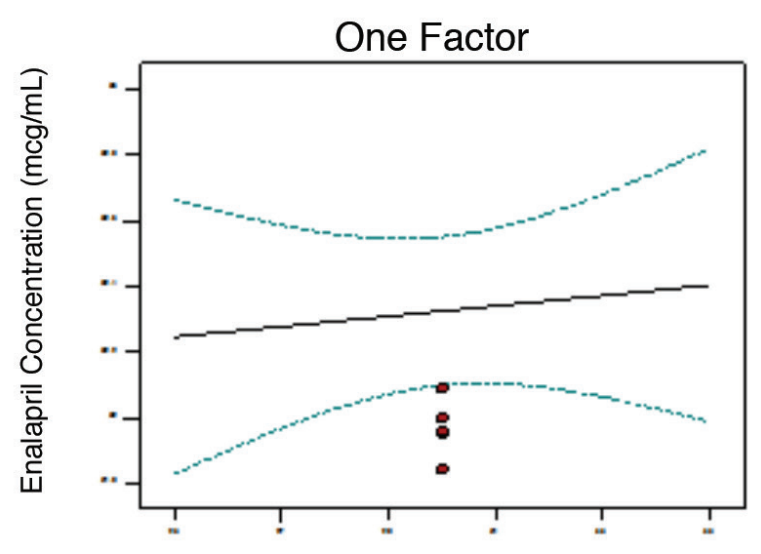

A: Column Temperature (Celcius)

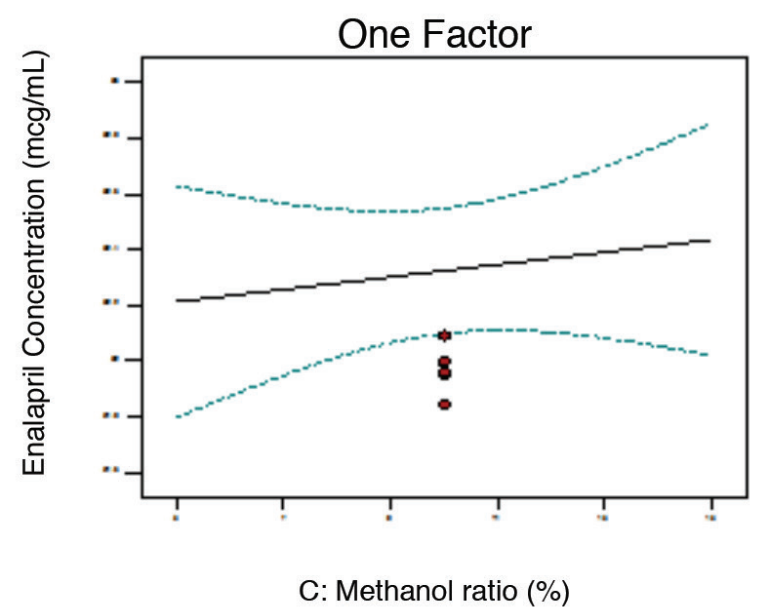

previously published methods. ${ }^{24-26}$ The lower concentrations are considered for the first minutes of the dissolution study, and higher values are for the assay.

\section{Accuracy}

Accuracy was demonstrated using six different solutions, containing $1.39,2.78,5.56,12,16$, and $19.2 \mu \mathrm{g} / \mathrm{mL}$ of amlodipine and $2.78,5.56,11.12,24,32$, and $38.4 \mu \mathrm{g} / \mathrm{mL}$ of enalapril maleate. Recovery values were obtained within the range of $98.6 \%$ $101.6 \%$. The low value of relative standard deviation (RSD) less than $1 \%$ indicates that the proposed method is accurate. Results are presented in Table 5.

Table 4. Calibration data for amlodipine and enalapril maleate $(n=3$ for each level) for the optimized method

\begin{tabular}{lll} 
APls & Equation & $\mathrm{R}^{2}$ \\
\hline Amlodipine & $\mathrm{y}=4253.2 \mathrm{x}-796.1$ & 0.9998 \\
\hline Enalapril maleate & $\mathrm{y}=6272.4 \mathrm{x}-1177.1$ & 0.9995 \\
\hline
\end{tabular}

$R^{2}$ : R-square

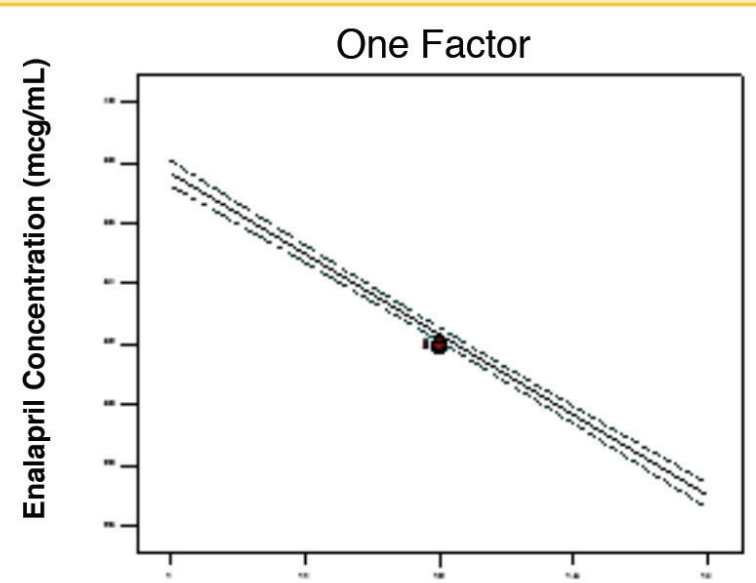

B: Flow Rate (mL/min)



Figure 4. A-D) One-factor graphs of the main effects of the factors on enalapril concentration 


\section{Repeatability}

Repeatability is also termed intraday precision and provides information about the precision under the same operating conditions in a short time interval. ${ }^{47}$ Repeatability was assessed using 10 determinations of the solutions including $16 \mu \mathrm{g} / \mathrm{mL}$ of amlodipine and $32 \mu \mathrm{g} / \mathrm{mL}$ of enalapril maleate. The recovery values were $99.9 \pm 0.31 \%$ and $100 \pm 0.07 \%$ for amlodipine and enalapril maleate, respectively.

The RSDs were $0.307 \%$ and $0.0711 \%$ for amlodipine and enalapril maleate, respectively.

\section{Intermediate precision}

Intermediate precision was assessed using the interday variations. Two different concentrations ( 4 and $16 \mu \mathrm{g} / \mathrm{mL}$ for amlodipine and 8 and $32 \mu \mathrm{g} / \mathrm{mL}$ for enalapril maleate) were analyzed on three consecutive days. The RSD values of interday precision were less than $1 \%$, confirming the method precision. The results are given in Table 6.

The low RSD value for intermediate precision and repeatability of the method as well as within-day and day-to-day variation

Table 5. Accuracy results for amlodipine and enalapril maleate $(n=3$ for each level)

\begin{tabular}{llll} 
& $\begin{array}{l}\text { Concentration } \\
(\mu \mathrm{g} / \mathrm{mL})\end{array}$ & $\begin{array}{l}\text { Recovery } \\
(\% \pm \mathrm{SE})\end{array}$ & RSD $(\%)$ \\
\hline & 1.39 & $99.0 \pm 0.70$ & 0.68 \\
Amlodipine & 2.78 & $98.6 \pm 1.60$ & 1.59 \\
& 5.56 & $100.0 \pm 0.40$ & 0.42 \\
& 12.0 & $100.1 \pm 0.30$ & 0.27 \\
& 16.0 & $99.7 \pm 0.16$ & 0.16 \\
& 19.2 & $101.1 \pm 0.40$ & 0.40 \\
\hline Enalapril & 2.78 & $100.4 \pm 0.60$ & 0.64 \\
maleate & 11.12 & $99.6 \pm 0.10$ & 0.08 \\
& 24.0 & $100.6 \pm 0.10$ & 0.10 \\
& 32.0 & $100.0 \pm 0.20$ & 0.19 \\
& 38.4 & $99.7 \pm 0.25$ & 0.26 \\
& $101.6 \pm 0.30$ & 0.28
\end{tabular}

SE: Standard error, RSD: Relative standard deviation suggested that the method was precise within the range of measurement.

Limit of detection (LOD) and limit of quantification (LOQ)

LOD and LOQ were calculated based on the SD of the response and the slope by using the equations below:

$$
\begin{array}{ll}
L O D=\frac{3.3 \times \sigma}{S} & (\text { Equation 3) } \\
L O Q=\frac{10 \times \sigma}{S} & \text { (Equation 4) }
\end{array}
$$

where $\sigma$ is the SD of the response, and $S$ is the slope of the calibration curve. According to the equations, LOD values were $0.0631 \mu \mathrm{g} / \mathrm{mL}$ and $0.0424 \mu \mathrm{g} / \mathrm{mL}$ and LOQ were $0.19 \mu \mathrm{g} / \mathrm{mL}$ and $0.129 \mu \mathrm{g} / \mathrm{mL}$ for amlodipine and enalapril maleate, respectively. The LOD and LOQ results suggested that the method was highly sensitive.

\section{Stability}

The drugs dissolved in $0.1 \mathrm{~N} \mathrm{HCl}$ were stable when stored at $25^{\circ} \mathrm{C}$ for 72 hours. After 72 hours, drug recovery values were $99.7 \%$ for amlodipine and $99.4 \%$ for enalapril maleate.

\section{Assay in tablets}

The optimized method was used for the assay of amlodipine and enalapril in FDC tablets. An additional peak from excipients was not observed. The results were in the range of the labeled amount $\pm 5 \%$ for both drugs (Table 7 ).

\section{Dissolution}

Dissolution was performed with the in-house FDC tablet by using USP apparatus II in $0.1 \mathrm{~N} \mathrm{HCl}$. $0.1 \mathrm{~N} \mathrm{HCl}$ was selected as the model dissolution medium. The proposed HPLC method was available for dissolution of FDC tablets. Both amlodipine and enalapril were dissolved more than $85 \%$ within $10 \mathrm{~min}$. Dissolution profiles of amlodipine and enalapril were given in Figure 7. The dissolution media of $0.1 \mathrm{~N} \mathrm{HCl}$ replaces the artificial stomach medium that is frequently used with the

\begin{tabular}{|c|c|c|c|c|c|}
\hline & Concentration $(\mu \mathrm{g} / \mathrm{mL})$ & $1^{\text {st }}$ day $(\% \pm S E)$ & $2^{\text {nd }}$ day $(\% \pm S E)$ & $3^{\text {rd }}$ day $(\% \pm S E)$ & RSD (\%) \\
\hline \multirow{2}{*}{ Amlodipine } & 4.0 & $99.0 \pm 0.04$ & $98.3 \pm 0.02$ & $99.0 \pm 0.02$ & 0.754 \\
\hline & 16.0 & $99.9 \pm 0.06$ & $99.4 \pm 0.04$ & $99.7 \pm 0.03$ & 0.248 \\
\hline \multirow{2}{*}{ Enalapril maleate } & 8.0 & $99.3 \pm 0.02$ & $99.1 \pm 0.02$ & $99.0 \pm 0.10$ & 0.816 \\
\hline & 32.0 & $99.8 \pm 0.02$ & $99.8 \pm 0.02$ & $100.0 \pm 0.02$ & 0.111 \\
\hline
\end{tabular}
purpose of formulation development and quality control. For

SE: Standard error, RSD: Relative standard deviation

Table 7. Assay for FDC tablets $(n=3)$

\begin{tabular}{llll} 
& Labeled amount (mg/tablet) & Observed amount (mg/tablet) & RSD (\%) \\
\hline Amlodipine & 5.00 & $4.95 \pm 0.03$ & 0.52 \\
\hline Enalapril maleate & 10.00 & $10.17 \pm 0.06$ & 0.63 \\
\hline
\end{tabular}

FDC: Fixed-dose combination, RSD: Relative standard deviation 

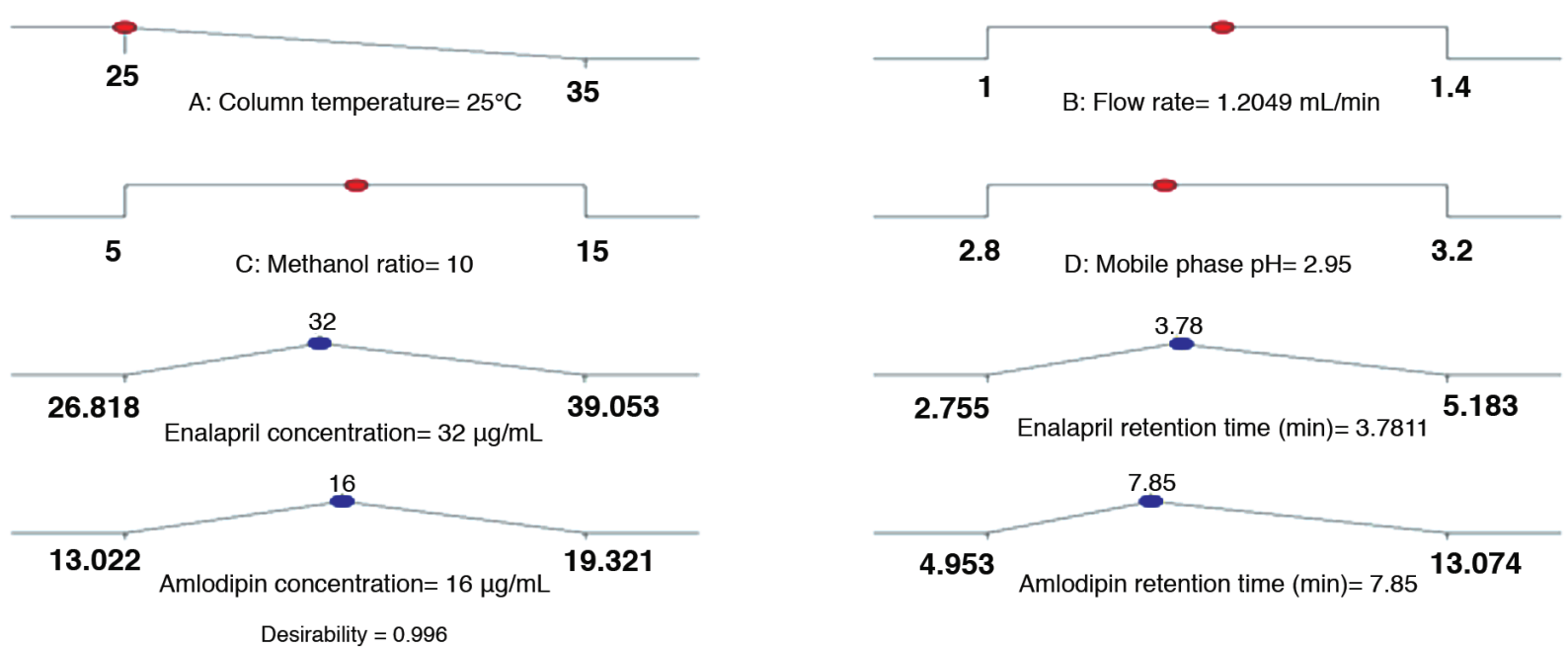

Figure 5. Optimization conditions of independent variables according to the Design Expert ${ }^{\circledR}$ Software

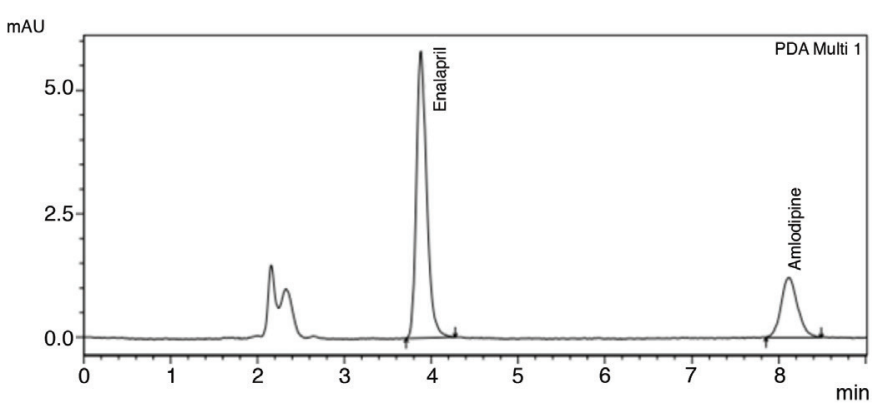

Figure 6. Chromatograms of enalapril ( $8 \mu \mathrm{g} / \mathrm{mL}$, as maleate) and amlodipine $(4 \mu \mathrm{g} / \mathrm{mL})$ in the optimized method

PDA: Photodiode array

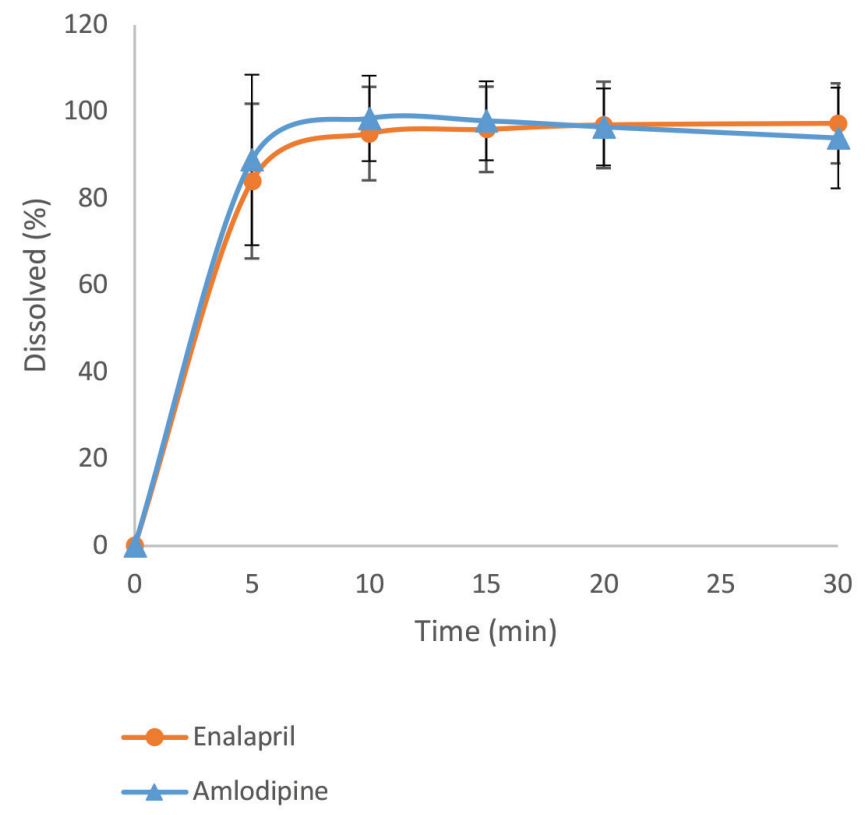

Figure 7. Dissolution results of amlodipine and enalapril in an in-house FDC product $(n=3)$

FDC: Fixed-dose combination using this analytical method for other dissolution media such as $\mathrm{pH} 4.5$ or $\mathrm{pH} 6.8$ there might be small modifications in chromatographic conditions.

\section{CONCLUSION}

In conclusion, an accurate, precise, specific, and environmentally appropriate HPLC method was developed and validated for amlodipine besylate and enalapril maleate in the typical dosage unit. The BBD, an optimization design, was used to evaluate the operational factors in a robustness test, and validation was performed according to international guidelines. The developed method was more economic and suitable for green chemistry with less solvent consumption, which improved column performance. The method was applied to assay and dissolution studies and was found suitable for quality control tests and in vitro performance of pharmaceutical dosage forms for a fixeddose tablet combination containing amlodipine besylate and enalapril maleate for the treatment of hypertension.

\section{ACKNOWLEDGMENTS}

The authors would like to thank Nobel Pharma (Turkey) for providing amlodipine besylate and enalapril maleate as gift samples.

Conflicts of interest: No conflict of interest was declared by the authors. The authors alone are responsible for the content and writing of the paper.

\section{REFERENCES}

1. Schellack N, Malan L. An overview of fixed-dose combinations of antihypertensive drugs in South Africa. S Afr Fam Prac. 2014;56:206211.

2. Mancia G, De Backer G, Dominiczak A, Cifkova R, Fagard R, Germano G, Grassi G, Heagerty AM, Kjeldsen SE, Laurent S, Narkiewicz K, Ruilope L, Rynkiewicz A, Schmieder RE, Struijker Boudier HAJ, Zanchetti A, Vahanian A, Camm J, Caterina R, Dean V, Dickstein K, Filippatos G, Funck- 
Brentano C, Hellemans I, Kristensen SD, McGregor K,Sechtem U, Silber S, Tendera M, Widimsky P, Zamorano JL, Kiowski W, Agabiti-Rosei E, Ambrosioni E, Lindholm LH, Viigimaa M, Adamopoulos S, Agabiti-Rosei E, Ambrosioni E, Bertomeu V, Clement D, Erdine S, Farsang C, Gaita D, Lip G, Mallion J-M, Manolis AJ, Nilsson PM, O'Brien E, Ponikowski P, Redon J, Ruschitzka F, Tamargo J, Zwieten P, Waeber B, Williams $B$, Management of Arterial Hypertension of the European Society of Hypertension, European Society of Cardiology. Guidelines for the management of arterial hypertension: the task force for the management of arterial hypertension of the European society of hypertension (ESH) and of the European Society of Cardiology (ESC). Eur Heart J. 2007;34:2159-2219.

3. Mancia G, Fagard R, Narkiewicz K, Redon J, Zanchetti A, Böhm M, Christiaens T, Cifkova R, De Backer G, Dominiczak A, Galderisi M, Grobbee DE, Jaarsma T, Kirchhof P, Kjeldsen SE, Laurent S, Manolis AJ, Nilsson PM, Ruilope LM, Schmieder RE, Sirnes PA, Sleight P, Viigimaa M, Waeber B, Zannad F, Task Force Members. Guidelines for the management of arterial hypertension: the task force for the management of arterial hypertension of the European society of hypertension (ESH) and of the European Society of Cardiology (ESC). J Hypertens. 2013;25:1105-1187.

4. Weir MR. Effect of renin angiotensin system inhibition on end organ protection: can we do better? Clin Ther. 2007;29:1803-1824.

5. European Medicines Agency, Committee for medicinal products for human use. Guideline on clinical development of fixed dose combination medicinal products; 2017. Available from: https://www.ema.europa.eu/ en/documents/scientific-guideline/guideline-clinical-developmentfixed-combination-medicinal-products-revision-2_en.pdf

6. Patel P, Ordunez P, DiPette D, Escobar MC, Hassel T, Wyss F, Hennis A, Asma S, Angell S, Standardized Hypertension Treatment and Prevention Network. Improved blood pressure control to reduce cardiovascular disease morbidity and mortality: the Standardized Hypertension Treatment and Prevention Project. J Clin Hypertens. 2016;18:1284-1294.

7. Shah SJ, Randall SS. Current trends of hypertension treatment in the United States. Am J Hypertens. 2017;30:1008-1014.

8. Sweetman SC. Martindale. The Complete Drug Reference. (36th ed). London, UK; Chicago, USA: Pharmaceutical Press; 2009:1214.

9. Shohin IE, Ramenskaya GV, Vasilenko GF, Maleshenko EA. In vitro dissolution kinetics of amlodipine tablets marketed in Russia under biowaiver conditions. Dissolution Techn. 2010;17:20-22.

10. Amidon GL, Lennernäs $H$, Shah VP, Crison JR. A Theoretical basis for a biopharmaceutic drug classification: The correlation of in vitro drug product dissolution and in vivo bioavailability. Pharm Res. 1995;12:413-420.

11. Kaynak MS, Bogacz A, Stelmasinski M, Şahin S. Bioavailability file: amlodipine. FABADJ Pharm Sci. 2011;36:207-222.

12. Verbeeck RK, Kanfer I, Löbenberg R, Abrahamsson B, Cristofoletti R, Groot DW, Langguth P, Polli JE, Parr A, Shah VP, Mehta M, Dressman JB. Biowaiver monographs for immediate release solid oral dosage forms: Enalapril. J Pharm Sci. 2017;106:1933-1943.

13. United States Pharmacopeia 40, Rockville, "Amlodipine tablets". 2017; 2773.

14. United States Pharmacopeia 40, Rockville, “Enalapril tablets". 2017; 3971.

15. Malesuik MD, Cardoso SG, Bajerski L, Lanzanova FA. Determination of amlodipine in pharmaceutical dosage forms by liquid chromatography and ultraviolet spectrophotometry. J AOAC Int 2006;89:359-364.
16. Lima DM, Dos Santos LD, Lima EM. Stability and in vitro release profile of enalapril maleate from different commercially available tablets: possible therapeutic implications. J Pharm Biomed Anal. 2008;47:934-937.

17. Bhardwaj SP, Singh S. Study of forced degradation behavior of enalapril maleate by LC and LC-MS and development of a validated stabilityindicating assay method. J Pharm Biomed Anal. 2008;46:113-120.

18. Naidu KR, Kale UN, Shingare, MS. Stability indicating RP-HPLC method for simultaneus determination of amlodipine and benazepril hydrochloride from their combination drug product. J Pharm Biomed Anal. 2005;39:147-155.

19. Kurbanoglu S, Gumustas M, Uslu B, Ozkan SA. A sensitive and selective RP-LC method for the simultaneous determination of the antihypertensive drugs, enalapril, lercandipine, nitrendipine and their validation. Chromatographia. 2013;76:1477-1485.

20. Al-Mahmud A, Bhadra S, Haque A, Al-Mamun E, Haider SS. Development and validation of HPLC method for simultaneous determination of gliclazide and enalapril maleate in tablet dosage form. Dhaka Uni J Pharm Sci. 2014;13:51-56.

21. Wankhede SB, Wadkar SB, Raka KC, Chitlange SS. Simultaneous estimation of amlodipine besylate and olmesartan medoxomil in pharmaceutical dosage form. Ind J Pharm Sci. 2009;71:563-567.

22. Sharma M, Kothari C, Sherikar O, Mehta PJ. Concurrent estimation of amlodipine besylate, hydrochlorothiazide and valsartan by RP-HPLC, HPTLC and UV spectrophotometry. J Chromatogr Sci. 2013;52:27-35.

23. Elsebaei F, Zhu Y. Fast gradient high performance liquid chromatography method with UV detection for simultaneous determination of seven angiotensin converting enzyme inhibitors together with hydrochlorothiazide in pharmaceutical dosage forms and spiked human plasma and urine. Talanta. 2011;85:123-129.

24. Chaudhari BG. Development and validation of RP-HPLC method for simultaneous estimation of enalapril maleate and amlodipine besylate in combined dosage form. J Appl Pharm Sci. 2012;2:54-57.

25. Tamboli AM, Chavan C, Mohite SK. Development and validation of a RPHPLC method for simultaneous determination of amlodipine besylate and enalapril maleate. J Pharm Res. 2010;3:2564-2567.

26. Masih M, Mittal A, Nandy BC. Development and validation of HPLC method for simultaneous estimation of amlodipine besylate and enalapril maleate in solid dosage form. World J Pharm Sci. 2014;2:1401-1405.

27. Korany MA, Mahgoub H, Haggag RS, Ragab MAA, Elmallah OA. Green Chemistry: Analytical and Chromatography. J Liq Chrom Rel Techn. 2017;40:839-853.

28. De Brito WA, Dantas MG, Nogueira FHA, Da Silva-Junior EF, De AraujaJunior JX, De Aquino TM, EAN Riberio, LG da Silva Solon, CFS Aragao, APB Gomes.. Development and validation of HPLC-DAD and UHPLCDAD methods for the simultaneous determination of guanylhydrazone derivatives employing a factorial design. Molecules. 2017;22:1-15.

29. Furlanetto S, Orlandini S, Mura P, Sergent M, Pinzauti S. How experimental design can improve the validation process. Studies in pharmaceutical analysis. Anal Bioanal Chem. 2003;377:937-944.

30. Kovacs B, Kantor LK, Croitoru MD, Kelemen EK, Obreja M, Nagy EE, Székely-Szentmiklósi B, Gyéresi A. Reversed phase HPLC for strontium ranelate: Method development and validation applying experimental design. Acta Pharm. 2018;68:171-183.

31. Sahu PK, Rao N, Cecchi T. An overview of experimental designs in HPLC method development and validation. J Pharm Biomed Anal. 2018;147:590611. 
32. Dhumal DM, Ganorkar SB, Patil MU, Singh D, Sharma MC, Bhadoriya KS. RP-HPLC-PDA analyses of tapentadol: application of experimental design. J Ana Chem Lett. 2016:214-223.

33. Ebrahimi-Najafabadi $H$, Leardi R, Jalali-Heravi M. Experimental design in analytical chemistry-part I: Theory. J AOAC Int. 2014;97:1-9.

34. Torbeck LD, Branning RC. The role of designed experiments. In: Torbeck $L D$, ed. Pharmaceutical and medical device validation by experimental design, New York: Informa Healthcare; 2007:98.

35. Karakucuk A, Celebi N, Teksin ZS. Preparation of ritonavir nanosuspensions by microfluidization using polymeric stabilizers: I. A design of experiment approach. Eur J Pharm Sci. 2016;95:111-121.

36. Ugurlu T, Karacicek U, Rayaman E. Optimization and evaluation of clarithromycin floating tablets using experimental mixture design. Acta Pol Pharm. 2014;71:311-321.

37. Sudha T, Divya G, Sujaritha J, Duraimurugan P. Review of experimental design in analytical chemistry. Indo Am J Pharm Res. 2017;7:550-565.

38. Casian T, Lurian S, Bogdan C, Rus L, Moldovan M, Tomuta I. QbD for paediatric oral lyophilisates development: risk assessment followed by screening and optimization. Drug Dev Ind Pharm. 2017;43:1932-1944.

39. Araujo PW, Brereton RG. Experimental design I. Screening. Trend Anal Chem. 1996;15:26-31.

40. Chen JG, Glancy K, Chen X, Alasandro M. Investigation of pharmaceutical High-Performance Liquid Chromatography assay bias using experimental design. J Chromatogr A. 2001;917:63-73.

41. Achilli M, Romele L. Use of factorial experimental design for the rapid evaluation of main and interactive factors affecting linearity in calibration curves for sulfate analysis by ion chromatography. J Chromatogr A. 1997;770:29-37.

42. Ficarra R, Calabro ML, Tommasini S, Villari A, Melardi S, Coppolino S, Semreen M, Ficarra P. Determination of fludarabine in a pharmaceutical formulation by LC. J Pharm Biomed Anal. 1999;21:1077-1081.

43. Ficarra R, Calabro ML, Cutroneo P, Tommasini S, Melardi S, Semreen M. Validation of a LC method for the analysis of oxaliplatin in a pharmaceutical formulation using an experimental design. J Pharm Biomed Anal. 2002;29:1097-1103.

44. Ye C, Liu J, Ren F, Okafo N. Design of experiment and data analysis by JMP in analytical method validation. J Pharm Biomed Anal. 2000;23:582589.

45. Chaudhari SR, Shirkhedkar AA. Design of experiment avenue for development and validation of RP-HPLC PDA method for determination of apremilast in bulk and in in-house tablet formulation. J Anal Sci Tech. 2019;10:1-9.

46. Kashid AM, Ghorpade DA, Toranmal PP, Dhawale SC. Development and validation of reversed phase HPLC method for the determination of vildagliptin using an experimental design. J Anal Chem. 2015;70:510-515.

47. International Conference on Harmonization Guidelines. Validation of analytical procedures: test and methodology of the International Conference on Harmonization (ICH) 1995. Available from: https:// www.ema.europa.eu/en/documents/scientific-guideline/ich-q-2-r1validation-analytical-procedures-text-methodology-step-5_en.pdf

48. Ragonese R, Muholland M, Kalman J. Full and fractionated experimental designs for robustness testing in the high-performance liquid chromatographic analysis of codeine phosphate, pseudophedrine hydrochloride and chlorpheniramine maleate in a pharmaceutical preparation. J Chromatogr A. 2000;870:45-51.
49. Dejaegher B, Heyden YV. Experimental designs and their recent advances in set-up, data interpretation, and analytical applications. J Pharm Biomed Anal. 2011;56:141-158.

50. Vander-Heyden Y, Nijhuis A, Smeyers-Verbeke J. Guidance for robustness/ruggedness test in method validation. J Pharm Biomed Anal. 2001;24:723-753.

51. Chauhan A, Mittu B, Chauhan P. Analytical method development and validation: A concise review. J Anal Bioanal Tech. 2015;6:2155-9872.

52. Ferreira SLC, Bruns RE, Ferreira HS, Matos GD, David JM, Brandão GC, da Silva EGP, Portugal LA, dos Reis PS, Souza AS, dos Santos WNL. Box-Behnken design: an alternative for the optimization of analytical methods. Anal Chim Acta. 2007;597:179-186.

53. Hund E, Massart DL, Smeyers-Verbeke J. Comparison of different approaches to estimate the uncertainty of a liquid chromatographic assay. Anal Chim Acta. 2000;404:257-271.

54. Fabre H. Robustness testing in liquid chromatography and capillary electrophoresis. J Pharm Biomed Anal. 1996;14:1125-1132.

55. Gumustas M, Caglayan MG, Onur F, Ozkan SA. Simultaneous determination and validation of emtricitabine, rilpivirine and tenofovir from biological samples using LC and CE methods. Biomed Chromatogr. 2018;32:4158.

56. De Almeida Borges VR, Ribeiro AF, de Souza Anselmo C, Cabral LM, de Sousa VP. Development of a high performance liquid chromatography method for quantification of isomers $\beta$-caryophyllene and $\alpha$-humulene in copaiba oleoresin using the Box-Behnken design. J Chromatogr B. 2013;940:35-41.

57. Zacharis CK, Vastardi E. Application of analytical quality by design principles for the determination of alkyl p-toluenesulfonates impurities in Aprepitant by HPLC validation using total-error concept. J Pharm Biomed Anal. 2018;150:152-161.

58. Dragomiroiu GTAB, Cimpoieșu ADINA, Ginghina O, Baloescu C, Barca M, Popa DE, Ciobanu AM, Anuta V. The development and validation of a rapid HPLC method for determination of piroxicam. Farmacia. 2015;63:123-131.

59. Awotwe-Otoo D, Agarabi C, Faustino PJ, Habib MJ, Lee S, Khan MA, Shah RB. Application of quality by design elements for the development and optimization of an analytical method for protamine sulfate. J Pharm Biomed Anal. 2012;62:61-67.

60. Bai XL, Yue TL, Yuan YH, Zhang HW. Optimization of microwave-assisted extraction of polyphenols from apple pomace using response surface methodology and HPLC analysis. J Sep Sci. 2010;33:3751-3758.

61. Beg S, Kohli K, Swain S, Hasnain MS. Development and validation of RP-HPLC method for quantitation of amoxicillin trihydrate in bulk and pharmaceutical formulations using Box-Behnken experimental design. J Liq Chromatogr Relat Technol. 2012;35:393-406.

62. Gomes SV, Portugal LA, dos Anjos JP, de Jesus ON, de Oliveira EJ, David JP, David JM. Accelerated solvent extraction of phenolic compounds exploiting a Box Behnken design and quantification of five flavonoids by HPLC-DAD in Passiflora species. Microchem J. 2017;132:28-35.

63. Inssane B, Charrouf M, Abourriche A, Abboud Y, Bouabidi A, Bennamara A, Saffaj T. Optimization and validation of a new high-performance liquid chromatographic method for analysis of acetazolamide in tablets using Box Behnken statistical experiment design. Acta Chromatogr. 2011;23:41-57.

64. Jovanov P, Guzsvány V, Lazić S, Franko M, Sakač M, Šarić L, Kos J. Development of HPLC-DAD method for determination of neonicotinoids in honey. J Food Compos Anal. 2015;40:106-113. 
65. Mirza T, Tan HS. Determination of captopril in pharmaceutical tablets by anionexchange HPLC using indirect photometric detection; a study in systematic method development. J Pharm Biomed Anal. 2001;25:39-52.
66. Myers RH, Montgomery D, Anderson-Cook CM. Response surface methodology: process and product optimization using design experiments, ( $3^{\text {rd }}$ ed). New Jersey: Wiley Series In Probability and Statistics: 2009. 